\title{
Alternatives to Underground Nuclear \\ Power Plant Siting
}

12 April 1977

Prepared for

CALIFORNIA ENERGY RESOURCES CONSERVATION

AND DEVELOPMENT COMMISSION

1111 Howe Avenue

Sacramento, Calif. 95825

Contract No. 154-006 


\section{DISCLAIMER}

This report was prepared as an account of work sponsored by an agency of the United States Government. Neither the United States Government nor any agency Thereof, nor any of their employees, makes any warranty, express or implied, or assumes any legal liability or responsibility for the accuracy, completeness, or usefulness of any information, apparatus, product, or process disclosed, or represents that its use would not infringe privately owned rights. Reference herein to any specific commercial product, process, or service by trade name, trademark, manufacturer, or otherwise does not necessarily constitute or imply its endorsement, recommendation, or favoring by the United States Government or any agency thereof. The views and opinions of authors expressed herein do not necessarily state or reflect those of the United States Government or any agency thereof. 


\section{DISCLAIMER}

Portions of this document may be illegible in electronic image products. Images are produced from the best available original document. 


\section{ALTERNATIVES TO UNDERGROUND NUCLEAR \\ POWER PLANT SITING}

12 April 1977

Civil Operations

$900^{\circ}$ THE AEROSPACE CORPORATION
E1 Segundo, Calif. 90245

\section{Prepared for}

California Energy Resources Conservation and Development Commission 1111 Howe Avenue

Sacramento, Calif. 95825 
The presentation contains the results of a ten-week literature review of concepts for augmenting the safety of light-water moderated nuclear power plants as alternatives to underground siting. Two types of alternatives were considered. The first type, consisting of alternatives to LWR power production technology such as the high temperature gas reactors (HTGRs), the liquid-metal fast-breeder reactors (LMFBRs), etc., has been previously discussed. The second type, consisting of alternatives within LWR power production technology such as radioactive fission product containment methods, is presented here.

The review was restricted to evaluations of the effectiveness of each concept to achieve safety benefits, rather than the necessity for achieving the benefits. For this reason, it was implicitly acknowledged tiat underground siting was being studied to reduce the consequences of a hypothesized core melt accident. It is generally assumed that such accidents are very unlikely to happen. Nevertheless, a basic tenet of the review was that such an event was possible and underground siting alternatives might be found which were both effective and economically feasible. 


\section{Modifications to LWR Technology}

GENERAL CATEGORIES:

- SITING

- SYSTEM MODIFICATIONS 
A search was made of the open nuclear safety literature for all ideas with the potential for increased safety in the event of a core melt accident.

The literature is generally limited to conceptual studies of advanced safety concepts. Ideas from the literature were evaluated and screened for their potential application to systems for control of core melt accidents. Modifications to the published concepts have been suggested where they would, in principle, provide more complete control. The resulting conceptual systems were evaluated in terms of the criteria established. Technical goals were developed in order to provide a basis for evaluating concepts. Evaluation criteria have been subsequently listed in order to make visible the various issues of merit that apply to safety systems. None of the evaluation criteria is uniquely essential to an improved safety system.

For each of the system concepts considered in detail, technical problems were identified, and those problems that are fundamental feasibility issues were further subdivided in terms of key technical uncertainties. Additional studies, which are evidently needed to achieve confidence in the feasibility of controlling core melts with the systems concepts analyzed, were also identified. 


\section{Scope}

- EXAMINE POSSIBLE SAFETY IMPROVEMENTS AGAINST CORE MELT IIN LWRS

- PROVIDE teCHNICAL goalS and eVAluation cRIteria

- eVAlUATE DESIGNS AGAINST CRITERIA. (SCREENING AND RANKING)

- delineate teChNical problems

- RECOMMEND FURTHER STUDIES 
Seventeen evaluation criteria were selected as figures of merit on white assies concepts. Criteria related to simplicity, passivity, and confidence are considered to be the most important of the listed parameters.

It is believed that the implementation cost of a meltdown control system should represent a small fraction of conventional LWR total plant cost (e.g., from 1 to, perhaps at most, 10 percent) and "reasonable" is meant to imply that range. This definition of "reasonable" was arbitrarily made and subjectively used for this review.

The criterion of not "jeopardizing": safety refers to advanced system design features that could cause new safety problems or reduce the effectiveness of other safety system components.

The "regulatory acceptability" criterion refers to the possibility of a system concept violating the extensive codified safety regulations of the NRC (e.g., 10 CFR50, etc.). For example, deliberate venting of radioactive fission products released during a meltdown accident would violate NRC regulations. System design features that would violate current regulations would clearly require changes in regulatory procedures and could substantially delay commercial applications of a concept.

"Improvements against external events" refers to the desire for a safety system to provide significant benefits even in the case of such extreme actions as war or sabotage. 


\section{Evaluation Criteria}

SIMPLICITY

SIMPLE MOVING PARTS

PASSIVITY

NO OPERATOR ACTION

NO ELECTRICAL I MECHANICAL SUPPORT

CONFIDENCE

ANALYSIS INSENSITIVE

EXPERIMENT INSENSITIVE

FEASIBLE TO DEMONSTRATE

IMPROVEMENTS AGAINST EXTERNAL EVENTS

ACCEPTABLE TO PUBLIC

LICENSABILITY

MAINTAINS CONTAINMENT

RETAINS ECCS

SAFETY NOT JEOPARDIZED

$\therefore$ REGULATORY ACCEPTABILITY

$\cos \mathrm{T}$

REASONABLE TEST. COST

FEASIBLE TO DEMONSTRATE

REASONABLE IMP.LEMENTA.TION COST

COST OF ACCIDENT

SAVES REACTOR

NO BALANCE-OF-PLANT DAMAGE

NO LONG-TERM MAINTENANCE 
The principal alternate siting options appear to be remote land-based and offshore (ocean) siting.

The specification of criteria for adequate remote siting is a complex issue for the extreme accidents hypothesized in this review. Moreover, as stated in the APS review of LWR safety (Ref. 7)," . . it may be quite difficult to site a reactor so remotely as to reduce the average expected population dose from a major release of radioactivity by as much as an order of magnitude." Thus, siting remoteness should continue to be an important ER CDC criterion, but it may have a limited potential for significant safety benefits for severe accidents.

Offshore plants of current designs do not appear to offer significant safety advantages against meltdowns. If a massive melt occurred in such an offshore plant, the core could melt through the reactor containment (including many feet of concrete), fall to the ocean floor, and potentially result in dispersal and possitle biological concentration of the nonvolatile fission products, including several tons of plutonium. The principal motivations for offshore barge siting are increased site availability and improved economics rather than major safety improvements. The potential opportunity for remote siting is perhaps the most attractive safety benefit of the concept. However, the narrow continental shelf along the California coast severely limits the availability of remote offshore sites. Accordingly, offshore siting was not judged to have potential safety improvements comparable to underground siting. 


\section{Alternative Siting of Above-Ground Nuclear Power Plants}

\begin{tabular}{|c|c|}
\hline SITING MODE & PROBLEM \\
\hline REMOTE LAND-BASED & DEFINITION OF ACCEPTABLE RADIUS \\
& $\begin{array}{l}\text { DEFINITION OF ACCEPTABLF } \\
\text { POPULATION DENSITY }\end{array}$ \\
\hline OFFSHORE & NO EXTRA PROTECTION AGAINST CORE MELT \\
& DISPERSAL OF CORE \\
& MARINE BIOLOGICAL CONCENTRATION \\
& OF CORE ELEMENTS \\
\hline
\end{tabular}


As will be noted in more detail, later in this discussion, various potential safety features of the kind listed here have been considered for amelioration of core melt consequences.

Countless safety improvements have been proposed for LWRs in the literature. Most of them apply to accidents of less severity than Class 9 accidents and have been eliminated from discussion on that basis. However, some suggestions have been made for improvements which could be incorporated into a system for complete control of a massive core melt. These features have been combined in the several comprehensive safety systems reviewed in detail hereafter. 


\section{LWR System Modifications.}

- AVOIDANCE OF STEAM EXPLOSIONS

- coRe CATCHERS

- BLOWOUT CHAMBERS

- FILTERED VENTING

- PASSIVE CONTAINMENT COOLING 
As indicated previously, the basic goal of this study was the identification of concepts which attempt to improve LWR safety with the objective of completely controlling meltdowns. Complete control does not necessarily mean complete containment of all radioactive fission products released in the accident. For example, containment of all fission products other than noble gases in a massive core-melt accident would reduce resultant whole-body doses to the public by more than a factor of 100 .

Simplicity and passivity are both considered important ingredients of high confidence safety systems. Passivity implies two types of requirements. That is, the system should ideally function with neither operator action nor electrical/mechanical support equipment needed. Passivity is also a relative concept, however. This is, a system that only required operators to initiate actions at the start of a meltdown would be superior to one requiring continual operator intervention for 6 months. A system that could be passively self-contained for 24 hours would be much superior to one that could violate containment within 2 hours. A totally passive system is conceivable, but not necessarily at acceptable cost. Hence, cost is another goal that must not be neglected in the systems evaluation. 


\section{Technical Goals}

- IMPROVED SAFETY FOR ABOVE-GROUND REACTORS

- COMPLETE CONTROL OF CORE MELT ACCIDENT (NOT NECESSARILY COMPLETE CONTAINMENT)

- SIMPLE SOLUTIONS

- PASSIVE METHODS

- HIGH CONFIDENCE IN PERFORMANCE 
The general sequence of events associated with a hypothesized massive core melt appears to be fairly well established within the literature. The usual initiating event is taken to be a loss-of-coolant accident (LOCA). Other initiating events, however, such as total electrical power failure or acts of sabotage are also potential sources of Class 9 accidents.

It is generally agreed that a massive core melt will eventually lead to melt-through of the reactor pressure vessel and core penetration through the outer containment building. Overpressurization of the containment with resulting uncontrolled venting is a probable consequence if some mechanism for pressure relief is not provided. It is not certain, however, that steam or hydrogen-air explosions will occur, or that massive venting will result from the core entering the earth, or that fission product heating will in itself fail the containment walls. Most sources, however, agree that the possibility of steam explosions cannot be neglected when the core melts through the pressure vessel when water has collected beneath the reactor as a result of blowdown and Emergency Core Cooling System (ECCS) operation. Similarly, the probability of unrestricted venting of radioactive fission products from the containment increases as the containment overpressure increases prior to melt-through. 


\section{Possible LOCA Sequence Massive LWR Core Melt}

EVËNT

- BLOWDOWN OF PRIMARY COOLANT

- eCCS INJECTION

- bOILING IN PRESSURE VESSEL

- CORE OVERHEATS

- STEAM GENERATION

- ZIRCALLOY OXIDATION

- $\mathrm{H}_{2}$ GAS

- $\mathrm{H}_{2}$ EXPLOSIONS

- CORE MELTS

- VOLATHLE FISSION PRODUCTS

- CORE SLUMPS

- STEAM EXPLOSIONS

- CORE MELT THROUGH

- STEAM EXPLOSIONS

- STEAM GENERATION

- CORE ATTACKS CONCRETE FLOOR

- STEAM GENERATION

- $\mathrm{CO}_{2}$ GAS RELEASE

- CORE PENETRATES CONTAINMENT

- FISSION PRODUCT VENTING

- STEAM EXPLOSIONS

- STEAM GENERATION

- CORE PENETRATES EARTH

- CONTAINMENT OVERPRESSURE BY

- WATER + DECAY HEAT STEAM

- $\mathrm{H}_{2}$

- $\mathrm{H}_{2} \mathrm{O}$ AND $\mathrm{CO}_{2}$ FROM CONCRETE

- CONTATNMENT HEÁT (DECAY HEAT) FAILS CONTAINMENT WALLS THERMALLY 
From the literature review, specific subsystem modifications were identified which addressed the control of single aspects of a Class 9 accident. Four key design problems were defined and are identified in the following shart. Subsystems that solve sequences previously described were combined into total system concepts designed to achieve complete control of the meltdown processes. 


\section{Systems Approach}

- SUBSYSTEM MODIFICATIONS

- SPECIFIC DESIGN PROBLEM SOLUTIONS

- SYSTEM CONCEPTS

- MULTIPLE COMBINATIONS OF́ MODIFICATIONS TO ACHIEVE COMPLETE CONTROL 
The left-hand column of this chartidentifies the four key problem areas that are considered crucial in the control of a large-scale meltdown. Neither the categorical solutions nor the list of candidate components is considered to comprise a complete list. Various combinations of the identified methods of safety augmentation are possible. For some of the accident phenomena described in a previous chart, it might be necessary or desirable to employ several of the suggested methods. On the other hand, some methods help prevent more than-one phenomenon. For example, employing a core catcher to avoid concrete-core interactions and the associated $\mathrm{CO}_{2}$ generation also prevents core penetration. Not all of the solutions are passive, nor are all equally feasible. 


\section{Published Methods on Core Melt Safety}

\begin{tabular}{|c|c|c|}
\hline $\begin{array}{r}\text { DESIGN } \\
\text { PROBLEM } \\
\end{array}$ & SOLUTION & METHOD \\
\hline $\begin{array}{l}\text { STEAM } \\
\text { EXPLOSIONS }\end{array}$ & $\begin{array}{l}\text { BLAST SHIELDS } \\
\text { DRY SUBREACTOR SPACE } \\
\text { MISCELLANEOUS (BMI-1910) }\end{array}$ & $\begin{array}{l}\text { SHIELDSS AROUND BLAST LOCATIONS } \\
\text { DRAINS BENEATH PRESSURE VESSEL } \\
\text { INHIBITORS; SATURATED WATER; CORE GUIDES } \\
\end{array}$ \\
\hline $\begin{array}{l}\text { CORE PENETRA- } \\
\text { TION OF } \\
\text { CONTAINMENT }\end{array}$ & CORE CATCHER WITH HEAT REMOVAL & $\begin{array}{l}\text { WATER-IMMERSED CORE-CATCHER } \\
\text { ACTIVELY-COOLED CORE CATCHER } \\
\text {-MASSIVE MELTING BED } \\
\end{array}$ \\
\hline $\begin{array}{l}\text { VAPOR-GENER- } \\
\text { ATED OVER-- } \\
\text { PRESSURIZA- } \\
\text { TION }\end{array}$ & $\begin{array}{l}\text { COOL DRY CORE CATCHER } \\
\text { BLOWOUT CHAMBERS } \\
\text { VENTING } \\
\text { SEPARATE WATER FROM ALL DECAY HEAT } \\
\text { AVOID CONCRETE-CORE INTERACTIONS } \\
\text { AVOID CONCRETE HEATING BY VOLATILE.F.P. } \\
\mathrm{H}_{2} \text { REMOVAL }\end{array}$ & $\begin{array}{l}\text { ACTIVELY-COOLED CORE CATCHER } \\
\text { TUNNEL OR CHAMBER } \\
\text { FILTERED VENTING } \\
\text { THERMALLY DISTANT WATER DRAIN VALUME } \\
\text { CORE CATCHER. } \\
\text { VENT HOT GASES, } \\
\text { HEAT REMOVAL } \\
\text { BASALTIC CONCRETE } \\
\text { SPARK PLUGS } / 0_{2} \text { SOURCE } \\
\text { CHEMICAL REACTIONS } \\
\end{array}$ \\
\hline $\begin{array}{l}\text { LONG-TIME } \\
\text { HEAT } \\
\text { REMOVAL }\end{array}$ & $\begin{array}{l}\text { REMOVE HOT GASES FROM CONTAINMENT } \\
\text { PASSIVE COOLING OF CONTAINMENT } \\
\text { SURFACE } \\
\text { ACTIVE COOLING }\end{array}$ & $\begin{array}{l}\text { VENT HOT GASES TO HEAT SINK / VENT; WET MELT } \\
\text { IMMERSED STEEL CONTAINMENT BUILDING; } \\
\text { WET MELT } \\
\text { POROUS CONCRETE HEAT SINK } \\
\text { MANY }\end{array}$ \\
\hline
\end{tabular}


This chart describes a concept from the nuclear safety literature (Ref. 2) for avoiding much of the vapor generation of a core melt. Drains keep the space under the reactor dry, avoiding the potential for massive steam explosions that might be expected upon vessel meltthrough. Hydrogen generation might also be reduced. The molten core, with its nonvolatile fission products and associated decay heat, would be caught in a bed of oxides with immense thermal capacity that is free of water and $\mathrm{CO}_{2}$ sources. The material for the bed should have as low a melting point as is feasible. The melting temperature must be low enough to avoid damaging the containment walls. The bed must have sufficient thermal capacity in its mass to prevent melt-through of the containment permanently.

Close examination of this concept reveals that long-term heating from the melting bed may induce boiling of the water in the sump ditch.

In addition, long-term cooling of the containment atmosphere is not provided for in the referenced concept. This is important since a sizeable fraction of all decay heat comes from volatilized fission products in a core melt accident. In this concept, without long-term atmospheric cooling, extreme temperatures could be reached within the containment. 


\section{Dry Melt + Massive Melting Bed}

\section{SUGGESTED CONCEPT}

- STEAM EXPLOSIONS

- BLAST SHIELDS

- DRAINS BENEATH PRESSURE VESSEL

- CORE PENETRATION OF CONTAINMENT

- MASSIVE MELTING BED

- VAPOR GENERATED OVER-PRESSURIZATION

- DRY MELT

- CARBONATE-FREE MELTING BED

- LONG-TIME HEAT REMOVAL

- ACTIVE COOLING

POTENTIAL PROBLEMS

- steam Production

- LONG-TIME HEAT REMOVAL

*Jan B. van Erp, Trans. ANS, V22, p. 468

(Reference 2*)

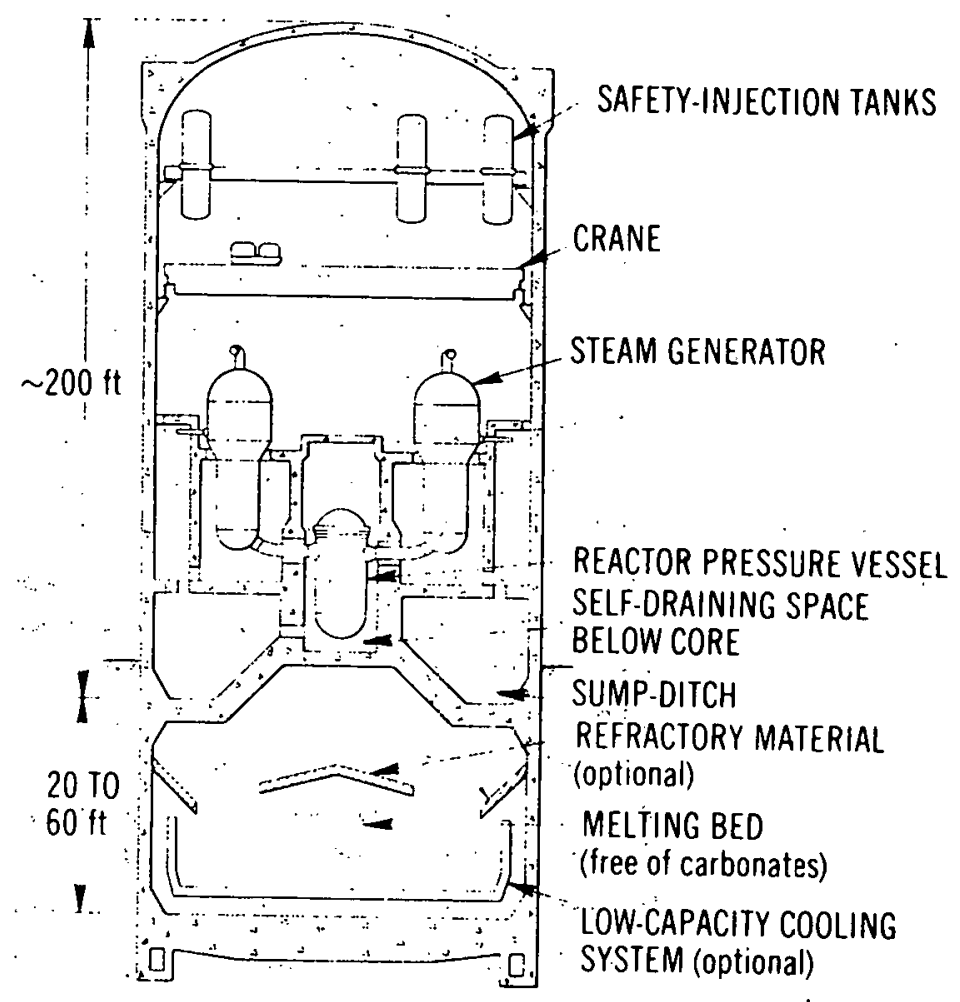


In order to address all four of the key design problems of core melt accidents, additions to the concept described in the previous figure have been incorporated in this chart. To prevent boiling of the cooling water collected in the sump ditch, that water could be drained to a thermally remote location. If that wate= were part of the emergency core cooling system and/or the containment cooling system, the draining could be initiated by the operator upon observation of loss of control in the hypothesized accident leading to meltdowr, or the distant sump could be designed to be an integra- part of the emergency core cooling system.

Additional expansion volume or filered venting could be included as a possible last resort against containment overpressur:zation in the event that excessive vapor generation could not be avoided.

Hydrogen removal or venting might also prove to be necessary since most of the zircalloy of the reactor fuel rods would be expected to react with steam generated prior to meltdown.

The suggested solution for long-time heat removal is the use of a massive heat sink within the containment, possibly as part of the containment walls. The use of thick porous concrete inner walls is representative of a possible heat sink for volatile and gaseous fission products within the augmented safety system. To illustrate the quantity of concrete required, 25,000 tons of concrete would have sufficient heat capacity to absorb all the decay heat of the volatile and gaseous fission products for 10 days. This amount of concrete is equivalent to that already used in some pressurized-water reactor (PWR) designs. Sizing of : the porous concrete heat sink would require more extensive thermal studies. Conduction out of the contairment to air can become a significant factor when tens of days are available. A smooth inner steel surface might be ised if numerous pressure-driven openings are included for admitting vapors into the concrete.

Technical uncertainties relevant to this concept include: melting bed technology, which has not been developed; damage to walls by $\beta$ and $\gamma$ activity from plated-out volatile fission products; and nonuniform heat dispersal within containment (i. e., local hot spot development). 


\section{Dry Melt + Massive Melting Bed}

POTENTIAL PROBLEMS

- STEAM PRODIUCTION

- DRAIN WATER tO REMOTE SUMP

- POSSIBLE BLOWOUT/VENTING

- POSSIBLE hYDROGEN REMOVAL

- LONG-TIME hEAT REMOVAL

- POROUS CONCRETE HEAT SINK

TECHNICAL UNCERTAINTIES

- MELTING BED TECHNOLOGY

- MATERIALS RESEARCH

- heat sink structural feasibility

- ENGINEEPING DESIGN

- Volatile F.P. plate OUt

- calculations of heat sinK RESPONSE TO SURFACE HEATING

- atMOSPHERIC heat tRANSFer and DISPERSAL

- detailed calculations

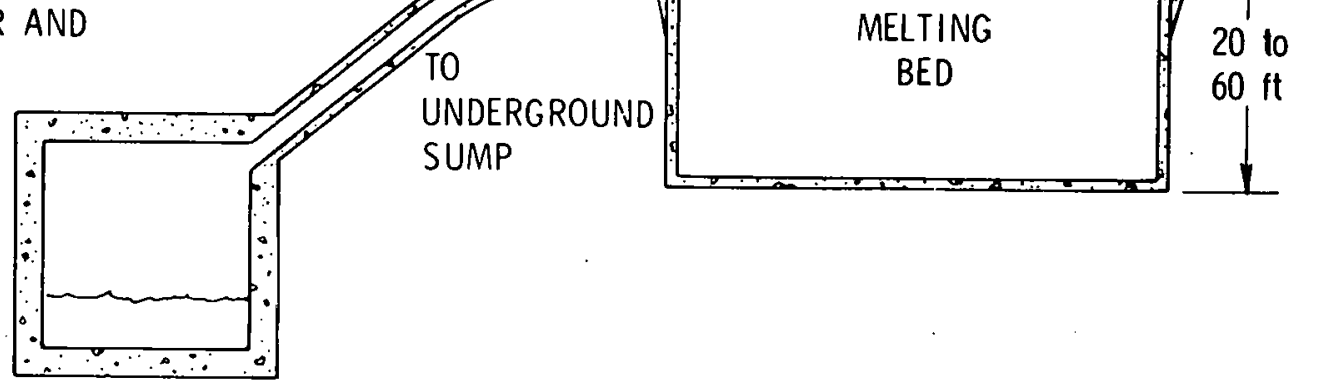


Reference 1 suggests that a thin steel containment shell, cooled by an exterior water heat sink, may be adequate to carry away all required decay heat, providing that steam condensation is available to enhance heat transfer on the inner surface. This concept thus requires a "wet melt" to provide a supply of atmospheric steam. A continuous supply of steam also prevents overheating of the air within the containment by volatile fission products. A water-immersed core catcher, also suggested by Ref. 1, appears to be the natural way to assure steam generation while solving the problem of core penetration of the containment floor. 


\section{Wet Melt + Steel Caisson}

JReference $1 *$ )

SUGGESTED CONCEPT

- SteAM EXPLOSIONS

- SEVERAL TECHNIQUES SUGGESTED

- CORE PEnetration OF CONTAINMENT

- WATER-IMMERSED CORE CATCHER

- late vapor generation

- STEAM CONDENSATION ON CONTAINMENT WALL

- LONG-TIIAE hEAT REMOVAL

- IMMiersed SteEl CONTAINMENT BIJILDING; WET MELT

POTENTIAL PROELEMS

- vapor generated

OVER-P RESSURIZATION

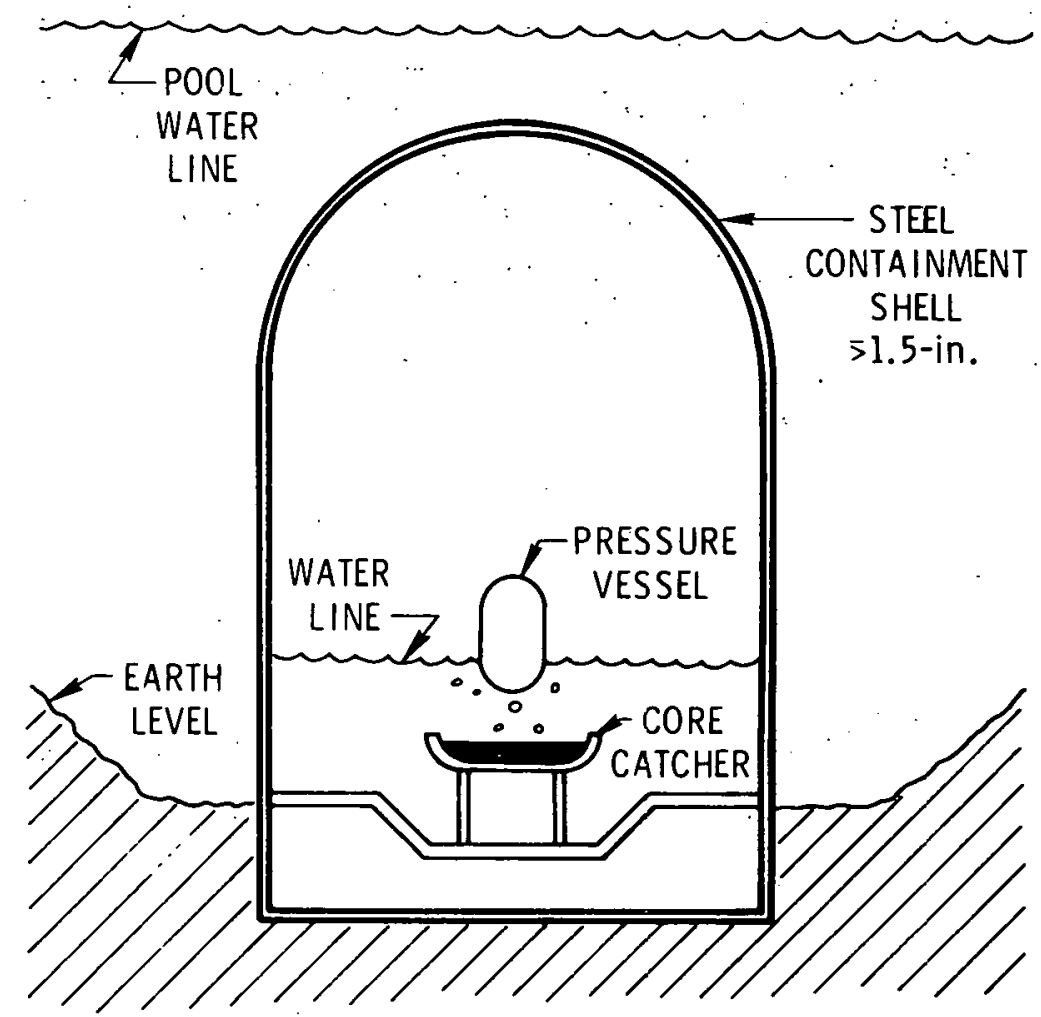

"D.L. Morrison at al, BMI-1910, July 1971 
If steam condensation alone is found to be incapable of preventing containment overpressurization, auxiliary means could be provided to reduce pressures, as indicated on the chart.

A number of areas of technical risk are also given on the chart. For example, this concept may be particularly susceptible to steam explosions as a result of the proposed water immersed core catcher. The capability of the condensation concept for vapor control should be evaluated with detailed calculations. The potential development of localized concentrated fission product hot spots should also be analyzed in detail to assure the adequacy of heat transfer from the containment. 


\section{Wet Melt + Steel Caisson}

POTENTIAL PROBLEMS

- VAPOR GENERATED OVER-PRESSURIZATION

- HYDROGEN BURNING

- TUNNEL DR CHAMBER

- filtere vi venting

TECHNICAL. UNCERTAINTIES

- STEAM EXPLOSIONS

- PHENOMENOLOGY AND dESIGN RESEARCH

- core catcher design

- VERIFICATION OF FEASIBILITY

- VAPOR VOLUME CONTROL

- detailed calculations

- atmospheric heat transfer and dispersal

- detailed calculations

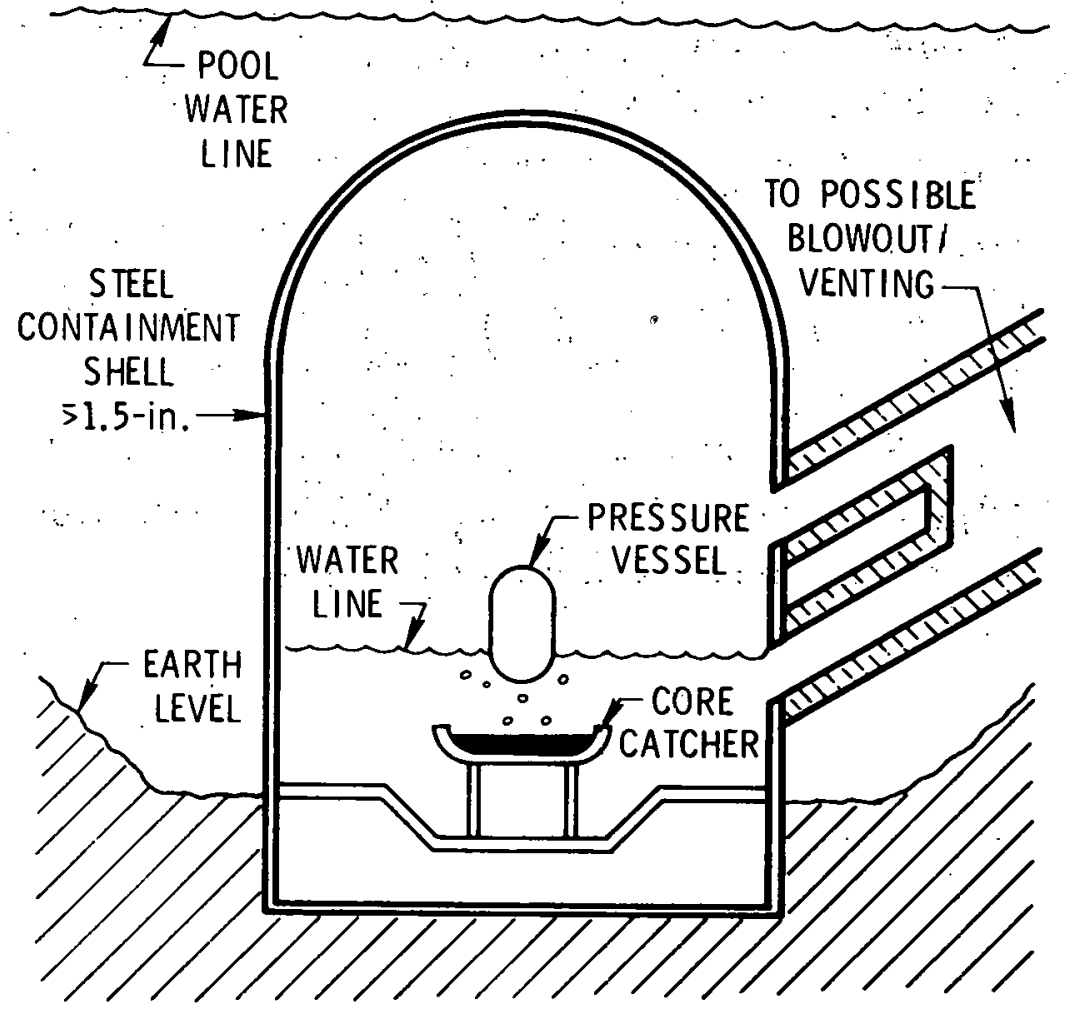


Reference 3 discusses the use of blowout chambers and filtered venting to accommodate vapor generation in the context of an underground siting concept. The problems of vaporgenerated overpressurization have been eliminated by allowing gases to be released from the primary and secondary containment to a buffer volume through pressure suppression and relief tunnels. If pressures increase subsequently beyond acceptable limits, filtered venting through a high stack is permitted for the gaseous and volatilized fission products. Though the concept reduces the risk of overpressurization by a controlled and filtered venting mechanism, it does increase risks to the public by allowing the venting of these fission products rather than providing complete containment.

Steam explosions were not considered in Ref. 3, perhaps due to reliance on underground siting. For an above-ground concept, however, it would be necessary to provide blast shields, etc. to minimize potential damages from steam explosions, if this concept were adopted.

Penetration of the containment floor by the molten core was not discussed, again perhaps relying on the underground siting for protection. For an above-ground application, inclusion of a core catcher would be necessary. 


\title{
Wet Melt + Blowout
}

\author{
(Reference $3^{*}$ )
}

SUGGESTED CONCEPT

- STEAM EXPLOSIONS

- NOT CONSIDERED

- CORE FENETRATION OF CONTAINMENT

- IMPLICITY ALLOWED lunderground plant)

- VAPOR GENERATED OVER-PRESSURIZATION

- BLOWOUT VOLUME

- eXPansion VOLUME

- FILTERED VENTING

- LONG-tIME heat REMOVAL

- STEAM-CARRIED TO

- BLOWOUT VOLUME

- EXIPANSION VOLUME

- FILTERED VENTING

\section{POTENTIALL PROBLEMS}

- STEAM EXPLOSIONS

- CORE PENETRATION OF CONTAINMENT

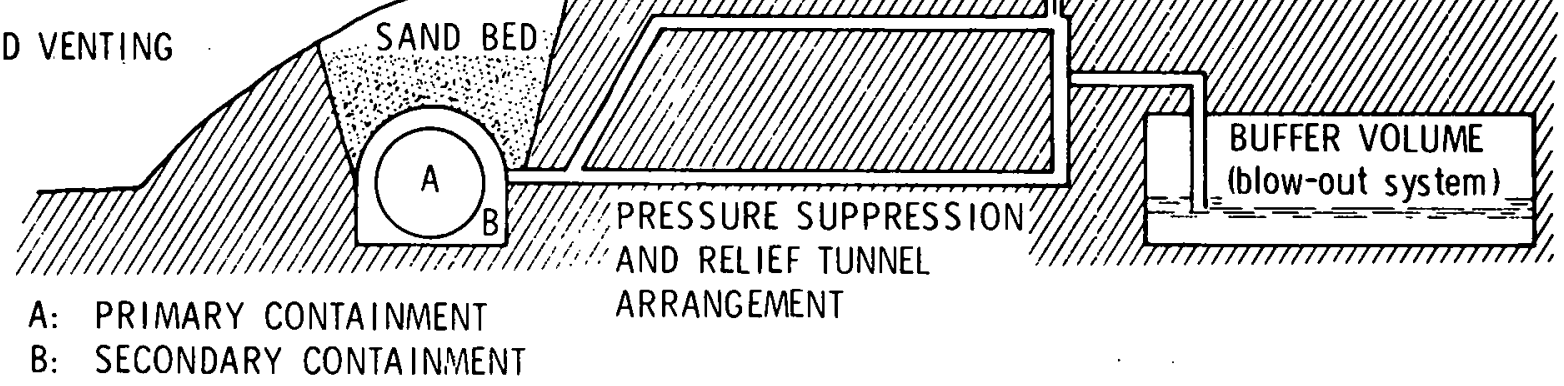

0. Orjasaeter, Report No. SS-11. Inst for Atomic Energy, Kjeller, Norway, Dec 1975 
For application of the concepts of Fief. 3 to an above-ground solution, it is suggested that the steam explosion threat be addressed by methods mentioned earlier.

The water-immersed core catcher of Ref. 1 has been incorporated to prevent containment melt-through. The core catcher would be kept under water by draining condensate from the expansion volume.

Again we find a number of a reas of technical uncertainty that deserve detailed engineering calculations. 


\section{Wet Melt + Blowout}

POTENTIAL PROBLEMS

- STEAM EXPLOSIONS

- SEVERAL TECHNIQUES POSSIBLE

- CORE PENETRATION OF CONTAINMENT

- WATER-IMMERSED. CORE CATCHER

TECHNICAL UNCER ${ }^{-}$AINTIIES

- STEAM EXPLOSIONS

- PHENOMENOLOGY AND DESIGN RESEARCH

- core catcher design

- VERIFICATION OF FEASIBILITY

- atmospheric heat tRansfer and dispersal.

- detaIled calculation

- volatile F. P. plateout/damage

- calculation of surface and fILter Response TO SURFACE HEATING

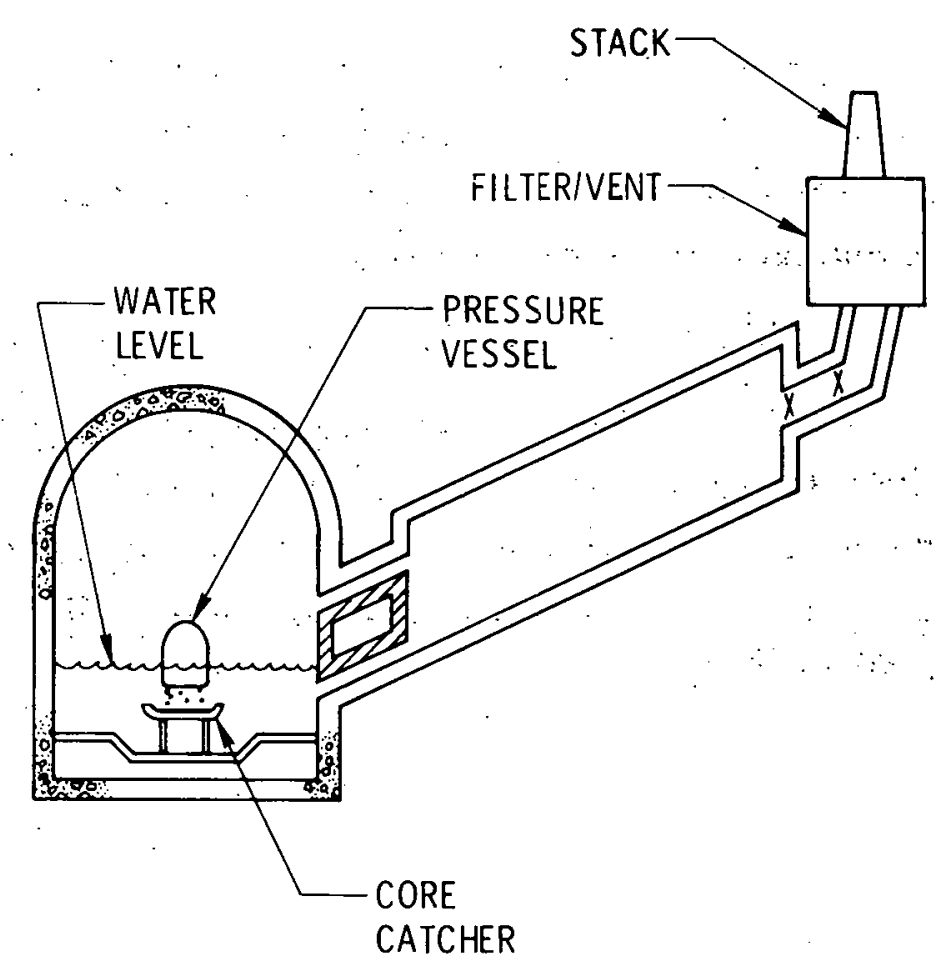


Reference 5 presents a different type of concept - a means of averting core melts passively by the use of a specially designed containment system. Automatic flooding of the core and spaces around the reactor vesse-is purportedly achieved with water from high pressure tanks which is stated to overwhelm any accident. A fairly complex configuration of valves, tanks, etc., is employed. This system is ostensibly simpler than a conventional ECCS and is passive in that it requires no active pumping system in its processes.

A possible problem may be encountered with the proposed passive heat exchangers for decay heat removal, which are connected to an outdoor pond. The small heat exchanger volume allowable within the containment makes it seem unlikely that adequate passive heat exchange can be engineered.

This system is claimed to be less expensive than a conventional containment and ECCS.

This system is beyond the conceptual stage, but has not been subjected to licensing or the intense scrutiny of conventional ECCS concepts. However, it is representative of a general clas of potentially very important safety augmentation concepts - alternate ECCS schemes - which would prevent meltdown rather than minimizing the consequences after an occurrence. 


\section{No Melt: "Passive Containment System"}

SUGGESTED CONCEPT

- STEAM EXPLOSIONS

- ELIMINATED

- CORE PENETRATION OF CONTA INMENT

- ELIMINATED

- VAPOR GENERATED OVER-PRESSURIZATION

- ELIMINATED

- LONG-TIME hEAT REMOVAL

- PASSIVE CONVECTIVE HEAT EXCHANGERS

POTENTIAL PROBLEMS

- LONG-TIME hEAT REMOVAL

"F. W. Kleimola, et al, Trans ANS 24, p 357 and reprint
(Reference $5^{*}$ )

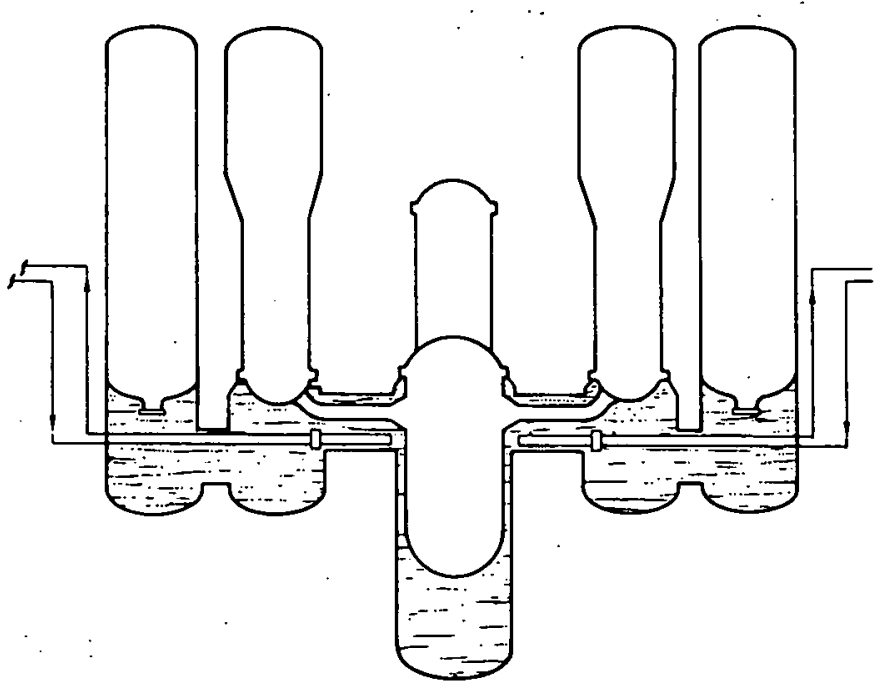


If passive heat exchange to the outdoor cooling water proves unworkable for the "Passive Containment System," an active system could be added.

There are technical uncertainties with this concept as there would be with any improved ECCS. In principle, however, it appears to offer the significant advantage of eliminating the meltdown. Its performance needs to je more thoroughly evaluated under accident conditions, however. 


\section{No Melt: "Passive Containment System"}

POTENTIAL PROBLEMS

- lONG-TIME heAt REMOVAl METHOD

- ACTIVE HEAT REMOVAL

TECHNICAL UNCERTAINTIES

- ENGINEERING DEMONSTRATION OF COMPLEX. SYSTEM UNDER ACCIDENT CONDITIONS

- PERFORMANCE STUDIES/ENGINEERING DEVELOPMENT

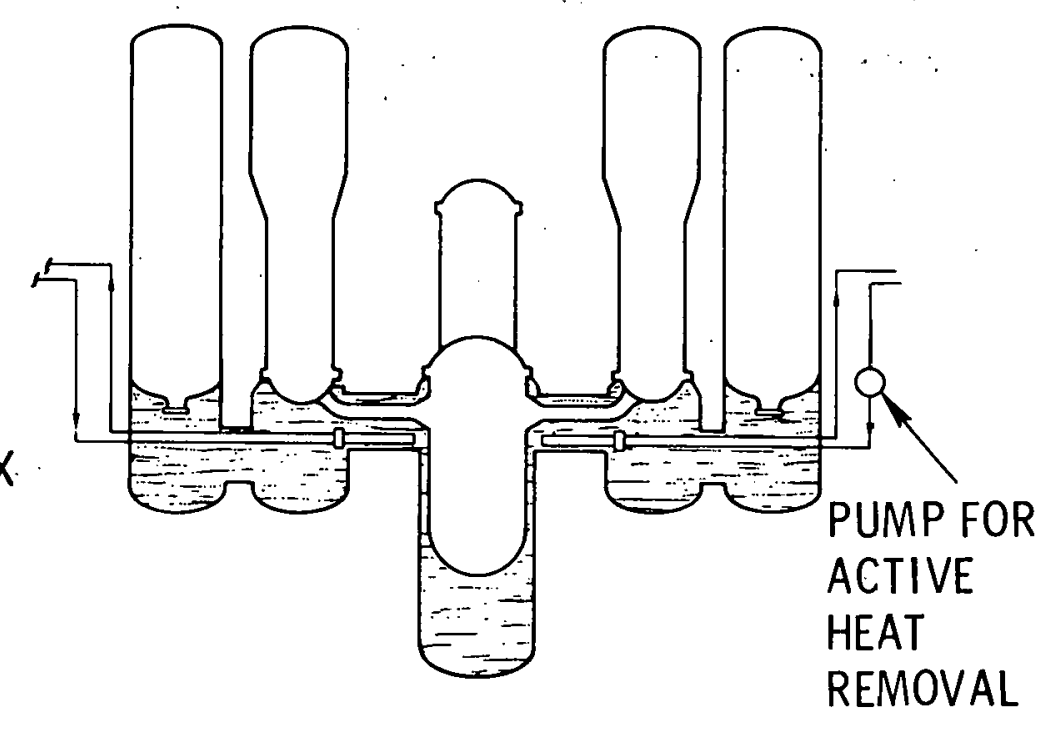

- UNPROVEN SUPERIORITY OVER CONVENTIONAL ECCS

- RISK/RELIABILITY ANALYSIS 
An attempt has been made to assigr ratings to the four system concepts discussed above in terms of the 17 evaluation criteria shown in this table. The rankings shown are subjectively based and consequently are of a qualitative nature. The results provide an overview of the quality of each of the systems analyzed relative to each criterion. Without the benefits of supplemental studies to define the costs, effectiveness, licensing impacts, and commercialization schedules for each system concept, it was deemed imprudent to specify aggregate rankings for the four systems. 


\section{Evaluation Criteria}

\begin{tabular}{|c|c|c|c|c|}
\hline & $\begin{array}{l}\text { DRY MELT + } \\
\text { MELTING BED }\end{array}$ & $\begin{array}{c}\text { WET MELT + } \\
\text { STEEL CAISSON }\end{array}$ & $\begin{array}{l}\text { WET MELT + } \\
\text { BLOWOUTT }\end{array}$ & $\begin{array}{l}\text { PASSIVE } \\
\text { CONTAINMENT } \\
\text { SYSTEM }\end{array}$ \\
\hline NO OPERATOR ACTION & 4 & 4 & 4 & 3 \\
\hline NO ELECTRICAL/MECHANICAL SUPPORT & 4 & 4 & 4 & 2 \\
\hline SIMPLE MOVING PARTS & 3 & 3 & 3. & 3 \\
\hline ANALYSIS INSENSITIVE & 3 & 2 & 3 & 3 \\
\hline EXPERI MENT INSENSITIIVE & 3 & 2 & 3 & 3 \\
\hline REASONABLE TEST COST & 2 & 2 & 2 & 3 \\
\hline REASONABLE IMPLEMENTATION COST. & 2 & 2 & 2 . & 4 \\
\hline FEASIBLE TO DEMONSTRATE & 2 & 2 & 2. & 3 \\
\hline MAINTAINS COVTAINMENT & 4 & 3 & 3 & 4 \\
\hline NO BALANCE-OF-PLANT DAMAGE & 4 & 4 & 4 & 4 \\
\hline SAVES REACTOR & 1 & 1 & 1 & 4 \\
\hline RETAINS ECCS & 4 & 3 & 4 & 1 \\
\hline NO LONG-TERM MAINTENANCE & 2 & 2 & 2 & 2 \\
\hline ACCEPTABLE TO PUBLIC & 4 & 3 & 3 & 2 \\
\hline SAFETY NOT JEOYPARDIZED & 4 & 2 & 3 & 4 \\
\hline REGULATORY ACCEPTABILITY & 4 & 3 & 2 & 4 \\
\hline IMPROVEMENT AGAINST EXTERNAL EVENTS & 4 & 3 & 3 & 1 \\
\hline
\end{tabular}

4. EXCELLENT 3-GOOD

2 - FAIR

l - POOR 
Some of the key technical uncertainties have been identified on earlier charts. That is, successful resolution of these items is believed to be required to establish the feasibility of the concepts. These key items are summarized on this chart.

Atmospheric heat transfer and dispersal has been identified in connection with three of the systems as a major issue. In this sense, the issue is related to the potential for development of localized fission product hot spots within the containment structure. Analyses would be required to evaluate the seriousness of this problem with respect to heat transfer within the systems.

The volatile fission product plateout/damage issue is associated again with uncertainty with respect to the uniformity of fission product deposition throughout porous concrete heat sinks and filters for controlled venting applications. Hot spot development within these materials could potentially lead to local failures of structures or filters. 


\section{Key Technical Uncertainties}

FUNDAMENTAL DESIGN FEASIBILITY ISSUES

- DRY MELT + MASSIVE MELTING BED

- VOLATILE F.P. PLATEOUT/DAMAGE

- ATMOSPHERIC HEAT TRANSFER AND DISPERSAL

- WET MELT + STEEL CAISSON

- ATMOSPHERIC HEAT TRANSFER AND DISPERSAL

- WET MELT + BLOWOUT

- ATMOSPHERIC hEAT TRANSFER AND DISPERSAL

- VOLATILE F.P. PLATEOUt/damage

- "PASSIVE CONTAINMENT SYSTEM"

- UNPROVEN SUPERIORITY OVER CONVENTIONAL ECCS 
A literature review of alternative safety augmentation concepts for surface plants has identified and categorized the principal system design problems associated with the control of a core melt accident. These design froblems were categorized as steam explosions, core penetration of the containment, vapor-generated overpressurization, and long-time heat removal. Subsystems that may be effective in solving these design problems as well as several approaches for developing these subsystems have been identified. Most of the solutions proposed in the literature were found to be incomplete in that not all of the principal design problems were addressed, i.e., the literature is primarily directed at subsystems rather than total systems. To the extent practicable within the review, total system concepts have been synthesized by selecting and combining compatible subsystems into four alternative system concepts. These concepts have been evaluated using a consistent set of evaluation criteria. 


\section{Summary}

- PRINCIPAL SYSTEM DESIGN PROBLEMS ASSOCIATED WITH CONTROLLING A CORE MELT ACCIDENT HAVE BEEN IDENTIFIED

- STEAM EXPLOSIONS

- CORE PENETRATION OF THE CONTAINMENT

- VAPOR GENERATED OVER-PRESSURIZATION

- LONG-TiME HEAT REMOVAL

- SUBSYSTEMS HAVE BEEN IDENTIFIED FOR SOLVING THE SPECIFIED DESIGN PROBLEMS, e.g..,

- BLAST SHIELDS

- CORE CATCHERS

- BLOWOUT CHAMBERS

- CONTROLLED VENTING

- PASSIVE CONTAINMENT COOLING

- PUBLISHED SYSTEM CONCEPTS HAVE BEEN MODIFIED TO RESPOND TO ALL IDENTIFIED DESIGN PROBLEMS

- DRY MELT + MASSIVE MELTING BED

- WET MELT + STEEL CAISSON

- WET MELT + BLOWOUT

- PASSIVE CONTAINMENT SYSTEM 
Within the underground siting study program, several of the alternative subsystem concepts identified in the review of alternative safety augmentations for surface power plants will be investigated for possible application as part of underground or berm contained systems. For example, blowout chambers, controlled venting, passive containment cooling, and massive heat sinks are candidate concepts for underground plants. The study of these subsystem concepts will contribute directly to a more complete understanding of their cost and effectiveness as potential components of surface power plants.

The literature review of alternative safety augmentation systems for surface power plants conducted thus far did not include studies to assess their cost and effectiveness, regulatory and licensing impacts, or the schedule associated with the development of commercial power plant technology: If such is sues are to be pursued, supplemental studies will be required. 


\section{Observations}

- THE UNDERGROUND STUDY PROGRAM WILL INVESTIGATE ONE OR MORE OF THE IDENTIFIED ALTERNATIVE SUBSYSTEMS

- SUBSTANTIAL SUBSYSTEM COST AND EFFECTIVENESS

DATA WILL BE DEVELOPED

- THE REVIEW OF ALTERNATIVE SAFETY AUGMENTATION SYSTEMS DID NOT INCLUDE SUPPLEMENTAL STUDIES TO ASSESS:

- COST AND EFFECTIVENESS

- REGULATORY/LICENSING ISSUES

- COMMERCIALIZATION SCHEDULES 
1. D. L. Morrison, et al., An Evaluaion of the Applicability of Existing Data to the Analytical Description of a Nuclear Reactor Accident, BMI-1910, Battelle Memorial Institute, Columbus, Ohio (July 19T1).

2. J. B. van Erp, "Containment Systems Aimed at Protecting Against the Consequences of Hypothetical Core-Melt Accidents, "Trans. ANS 22, p. 468 (1976).

3. O. Orjasaeter, Assessment of Hypothetical Maximum Accidents in an Underground PWR Plant, Report No. SS-11, Institute for Atomic Energy, Kjeller, Norway (November 1975).

4. Reactor Safety Study (Rasmussen Feport), WASH-1400 (NUREG-75/014), United States Nuclear Regulatory Commission (October 1975).

5. F. W. Kleimola, et al., "Passive Containment System," Trans. ANS 24, p. 357 (November 1976).

6: Thompson and Beckerley, Technology of Reactor Safety, Vol. II, MIT Press, Massachusetts Institute of Technology, Cambridge, MA (1973).

7. APS Study Group, "Report to the APS by the Study Group on Light-Water Reactor Safety;" Rev. Mod. Phys. 47, Suppl. 1 (Summer 1975), p. S106. 


\section{BIB LIOGRAPHY}

Denkins, R. F., and T. E. Northrup, "Concrete Containment Structures," Nuclear Safety $\underline{6}$ (2), p. 194-201 (Winter 1964-5).

Frank, M. V., et al., "Conceptual Design Approach to Containment of a Molten Core in Large Pressurized Water Reactors;" Trans. ANS 16, p. 208 (1973).

Anderson, R. P., and L. Bova, "The Role of Downfacing Burnout in Post-Accident Heat Removal," Trans. ANS 14, p. 294 (1971).

West, J. M., and W. D. Fletcher, "Molten Core Stopping Device," U.S. Patent No. 3,607,630, Se ptember 21, 1971.

Jansen, G., Jr., 'Nuclear Reactor Incorporating Means for Preventing Molten Fuel from Breaching the Containment Vessel Thereof in the Event of a Core Meltdown,"U.S. Patent No. 3, 702, 802, November 14, 1972.

Hesson, J. C., "Post-Accident Heat Removal and Fuel Containment in Reactor Vessel," Trans. ANS 14, p. 295 (1971).

Jansen, G., and D. D. Stepnewski, "Fast Reactor Fuel Interactions with Floor Material After a Hypothetical Core Meltdown," Nuclear Technology 17, p. 85 (January 1973).

Code of Federal Regulations, Chapter 10, Part 50 (1 January 1977).

Stern, C. D., Unconventional Nuclear Power Plant Siting Options and Water Resource Impacts, PB-248 460, Connecticut University (December 1975).

Jansen, G., et al., "Fast Reactor Fuel Interactions with Concrete After a Hypothetical Core Meltdown," Trans. ANS 13 , p. 376. 
Coats, R. L., Ed., Proceedings of Post-Accident Heat Removal (PAHR) Information

Exchange, Sandia Report No. SAND75-0497 (1975).

Gluekler, E. L., Status of Post-Accident Core Retention Concepts and Model, GEAP-14048, General Electric, Sunnyvale, California (July 1975).

Frewer, H., "Experience with Nuclear Fower Plant Siting in the Federal Republic of Germany," J. Br. Nucl. Energy Soc. 14 (3), p. 191 (1975).

Yadigaroglu, G., and S. O. Andersen, "Novel Siting Solutions for Nuclear Power Plants," Nuclear Safety 15 (6) (1974).

NSIC Staff, "Review of Methods of Mitigating Spread of Radioactivity from a Failed Containment System," ORNL-NSIC-27, Oakridge National Laboratories, Oakridge, Tennessee (September 1968).

APS Study Group, "Report to the APS by the Study Group on Light-Water Reactor Safety," Rev. Mod. Phys. 47, Suppl. 1 (Summer 1975).

Zivi, S. M., "A Passive Safety Device Against a Melt-Through Accident," Nuclear Appls. 5 , p. 53 (August 1968).

Liparulo, N. J., et al., "The Ice-Condenser System for Containment Pressure Suppression," Nuclear Safety 17 (6), p. 710 (1976).

van Erp, J. B., "Evolutionary Safety Developments for Nuclear Power Plants," Trans. ANS 21, p. 277 .

Sowa, E. S., and J. B. van Erp, "Development of Core-Retention Melting Beds for LWRs," Trans. ANS 22, p. 279. 
Baker, L., Jr., and R. O. Ivins, "Analyzing the Effects of a Zirconium-Water Reaction," Nucleonics 23 (July 1965).

Fontana, M. H., Ed., "Core Melt-Through as a Consequence of Failure of Emergency Core Cooling," Nuclear Safety $\underline{9}$ (1), p. 14 (February 1968).

Klepper, O. H., et al., "Underwater Caiss on Containment of Large Power Reactors," ORNL-4073, Oakridge National Laboratory, Oakridge, Tennessee (June 196.7).

A Floating Earthquake-Resistant Nuclear Power Station, Report No. 182-1-1, Daniel, Mann, Johnson, and Mendenhall (April 1968).

Baker, L., Jr., "Metal-Water Reactions," Nuclear Safety 8 (1) (1966). 